\title{
Study on different Agro Climatic Zone Wise of Black Bengal Goats Production Performance Suitable for Farming System in Jharkhand
}

\author{
Mukesh Kumar $^{1 *}$, Sushil Prasad ${ }^{1}$, Ravindra Kumar ${ }^{1}$, Soumen Naskar ${ }^{2}$, \\ Pankaj Kumar ${ }^{3}$, Pawan Kumar Verma ${ }^{1}$ and Nandani Kumari ${ }^{4}$ \\ ${ }^{1}$ Department of LPM, Ranchi Veterinary College, BAU, Ranchi, Jharkhand - 834006, India \\ ${ }^{2}$ ICAR-II AB, Namkum, Ranchi - 834010, India \\ ${ }^{3}$ LHS Wazirganj Gaya Bihar - 825412, India \\ ${ }^{4}$ Department of AGB, R.V.C, B.A.U, Ranchi, Jharkhand-834006, India \\ *Corresponding author
}

\section{A B S T R A C T}

Black Bengal farming is a traditional occupation and integral part of rural India's symbiotic system of agriculture and livestock production for Jharkhand, it is a legacy breed due to superior quality meat and skin-Black Bengal goat farming play an

Keywords

Performance and

Survivability of

Black Bengal goats, Black Bengal

farming

Article Info

Accepted:

12 May 2021

Available Online:

10 June 2021 important role in improving Black Bengal farming plays an important role in improving the socio- economic status of goat farmers was tribal/poor population of Jharkhand as compared to other livestock farming. The present investigations were carried out on Black Bengal goat maintained at AICRP BAU, from three agro climatic zone namely Central and North eastern plateau (IV), Western plateau (V) and South Eastern plateau (VI) Ranchi and Deoghar, East -singhbhum and lohardhaga were respectively selected for study. A cluster of four villages each from the four Districts above when villages namely Chamguru, Palajori, Barabanki and Tiko. Twenty farmers were each taken from each of the cluster making a total of Eighty farmers The study was conducted on 80 farmers, 1600 doe, 2499 kidding and their 4256 kids (male 2223 kids and female 2027 kids) during period six (6) years maintained under All India Coordinated Research Project on Goat Improvement [AICRP], Black Bengal field unit, BAU. From 2014 to 2020 Farmers having minimum numbers of 20goats were selected randomly. Reproductive and productive traits when studies in the experimental animals for molecular characterization for ten (10) goats were selected from each cluster village.

\section{Introduction}

Goat rearing is an essential part of the lives of the resource poor farmers in Jharkhand and of the rural economy. Goats are often referred to as the poor man's cow and contribute to the livelihoods of the farmers, especially for the women in the household. Goats are also an important part of the society and culture, especially for the tribal farmers and are the 
preferred meat during marriages and festivals despite its ever rising prices. At the global level, India stands second in goat population and accounts for $26 \%$ of global meat production. Small ruminant population of India, about 222.6 million heads of which about 148.88 million in goat(census 2019) in Jharkhand goat population 9.12 million (census2019) GDP is minimal (0.61) as compared with other sectors. Total milk production in India 187.75 million tone and $3 \%$ in the total milk production (BAHS2019) and goat meat production $13.53 \%$ in Jharkhand goat meat production 21.68 million tones. Meat production in India increased by $2.88 \%$ annually from 2009 to 2019 but demand continues to exceed supply in the country as well as in Jharkhand Rural economy of Jharkhand is dependable on agriculture and livestock. In the state most of the crop cultivation depends on rains and farmers earn substantial income from agriculture. The majority of available lands are undulated. Vagaries of rain due to climate change, soil erosion are major factors leading to uncertainty in crop production. In this situation importance of animal husbandry is increasing day by day and thus shall be able to provide a better and sustainable source of income for upliftment of rural economy. Under the animal husbandry sector goat and poultry rearing plays major role in the livelihood basket of farmers in Jharkhand scenario. The goat is a multi functional animal and plays a significant role in the economy as well as in nutrition of landless, small and marginal farmers in the district. For this reason, Mahatma Gandhi said goat as "Poor Man's Cow". Goat rearing is an enterprise which is practiced by a large section of population in rural areas of Jharkhand. Goats can efficiently survive on available shrubs and trees in an adverse harsh environment in low fertile lands where no other crop can be grown. In pastoral and agricultural subsistence societies in India, goats are kept as a source of additional income and as an insurance against disaster. Goats are also used in ceremonial feastings and for the payment of social dues. In addition to this, goat has religious and ritualistic importance in many societies. The advantages of goat rearing are:

\section{Materials and Methods}

The present investigations were carried out on Black Bengal goat maintained at AICRP BAU, from three agro climatic zone namely Central and North eastern plateau (IV), Western plateau (V) and South Eastern plateau (VI) Ranchi and Deoghar, East -singhbhum and lohardhaga were respectively selected for study. A cluster of four villages each from the four Districts above when villages namely Chamguru, Palajori, Barabanki and Tiko. Twenty farmers were each taken from each of the cluster making a total of Eighty farmers The study was conducted on 80 farmers, 1600 doe, 2499 kidding and their 4256 kids (male 2223 kids and female 2027 kids) during period six (6) years maintained under All India Coordinated Research Project on Goat Improvement [AICRP], Black Bengal field unit, BAU. From 2014 to 2020 Farmers having minimum numbers of 20 goats were selected randomly.

\section{Results and Discussion}

\section{Average body weight (kg) of black Bengal kids}

Average overall body weight $(\mathrm{kg})$ Black Bengal kids were observed to be $1.37 \pm 0.002$, $5.66 \pm 0.12, \quad 7.93 \pm 0.11, \quad 11.72 \pm 0.168$ and $14.00 \pm 0.31 \mathrm{~kg}$ at birth weight, $3^{\text {rd }}$ months, $6^{\text {th }}$ months $9^{\text {th }}$ months and $12^{\text {th }}$ months of age, respectively (Tables.1).

The results are in conformity with finding of Bhowmik et al., (2014) has observed that the average birth weight of Jamunapari, Black 
Bengal and cross bred goats were $1.53 \pm 0.22 \mathrm{~kg}, \quad 0.89 \pm 0.09$ and $1.26 \pm 0.20 \mathrm{~kg}$ respectively. Yadav and Khada (2009) observed the average body weight of male and female at three months ware 12.42 \pm 0.02 and $11.20 \pm 0.01 \mathrm{~kg}$ respectively for non-descript goats of 4 villages of Dungarpur district in Rajasthan.

Islam et al.,(2016) observed weight of female Black Bengal goats to be $7.12 \pm 0.14 \mathrm{~kg}$ under extensive system of management Singh and Singh (2000) found the average body weight at six months old Black Bengal goats was $8.206 \pm 0.200 \mathrm{~kg}$. The body weight of Black Bengal at 6-month of age was $7.01 \pm 0.90 \mathrm{~kg}$ as observed by Misra and Sinha (2001) Akhtar et al., (2006) observed that the mean body weight at six months of Black Bengal goats in three generations of selected and control groups were $7.98 \pm 0.29,7.63 \pm 0.67,9.88 \pm$ 0.82 and $6.82 \pm 0.08,7.00 \pm 0.17,6.93 \pm 0.31$ $\mathrm{kg}$ respectively. Yadav and Khada (2009) observed the 6-month body weight male and female in tribal villages of Dungarpur district in Rajasthan was 17.02 \pm 0.03 and $16.22 \pm$ $0.02 \mathrm{~kg}$ respectively Akhtar et al., (2006) observed that the mean body weight at nine months of Black Bengal goats in three generations of selected and control groups were $10.76 \pm 0.14,10.44 \pm 0.31,10.49 \pm 0.42$ and $9.79 \pm \quad 0.52, \quad 9.70 \pm 0.93, \quad 9.70 \pm 1.82 \mathrm{~kg}$ respectively.

Effect of growth performance in different sex of (Male and female) in kid's black Bengal goats

\section{Overall Kids Body Weight}

Average body weight gain of black bangle male and female kids during different periods (Months) of growth was observed to be $1.37 \pm 0.02, \quad 5.66 \pm 0.12, \quad 7.93 \pm 0.168$,
$11.72 \pm 0.168$ and $14.00 \pm 0.31(\mathrm{~kg})$ during birth weight, 3 th, $6^{\text {th }}, 9^{\text {th }}$ and $12^{\text {th }}$ months of age, respectively.

\section{Male Kids Body Weight}

Average body weight gain of black bangle male kids during different periods (Months) of growth was observed to be $1.38 \pm 0.18$, $6.15 \pm 0.15, \quad 8.23 \pm 0.20, \quad 12.74 \pm 0.14$ and $14.92 \pm 0.44(\mathrm{~kg})$ during birth weight, $3 \mathrm{th}, 6^{\text {th }}$, $9^{\text {th }}$ and $12^{\text {th }}$ months of age, respectively.

\section{Female Kids Body Weight}

Average body weight gain of black bangle female kids during different periods (Months) of growth was observed to be $1.34 \pm 0.07$, $5.18 \pm 0.05, \quad 7.66 \pm 0.09, \quad 10.55 \pm 0.18$ and $13.08 \pm 0.15(\mathrm{~kg})$ during birth weight, $3 \mathrm{th}, 6^{\text {th }}$, $9^{\text {th }}$ and $12^{\text {th }}$ months of age, respectively.

Significant different in body weight of birth $(p<0.05)$ were observed among different months. Highest birth weight was observed male kids followed by female kid's body weight (birth weight to $12^{\text {th }}$ of age) $\mathrm{kg}$. (Table 4.5 and fig 4.5). The results are in conformity with finding of Husain et al., (1996) observed on Black Bengal in Bangladesh that single kids had the highest gains followed by twins and triplets up to 6-months and thereafter this trend was not visible. They also recorded that the gains of triplets kids were the lowest but steady for 0-3 and 3-6 month whereas gains of single and twin kids sharply declined from 6-9 months. However, the 6-month body wt. of Black Bengal kids recorded in this study as $7.96 \pm 0.38 \mathrm{~kg}$ was within the range of $6.82 \mathrm{~kg}$ to $10.59 \mathrm{~kg}$ as observed by earlier workers at different times and different place. Husain et al., (1996) reported that the female kids had slightly higher gains than male though the difference was not significant. 
Table.1 Average body weight $(\mathrm{kg})$ of black Bengal kids

\begin{tabular}{|c|c|}
\hline Parameter & Overall \\
\hline Birth Weight & $\begin{array}{c}1.37 \pm 0.002 \\
(4256)\end{array}$ \\
\hline & $\begin{array}{c}\text { rd } \\
\text { rd }\end{array}$ \\
& $(2148)$ \\
\hline $6^{\text {th }}$ Months & $7.93 \pm 0.12$ \\
& $(928)$ \\
\hline $9^{\text {th }}$ Months & $\begin{array}{c}11.72 \pm 0.168 \\
(839)\end{array}$ \\
\hline $\mathbf{1 2}^{\text {th }}$ Months & $\begin{array}{c}14.00 \pm 0.31 \\
(341)\end{array}$ \\
\hline
\end{tabular}

Fig:- in parentheses indicate number of Kids

Table.2 Effect of growth performance in different sex of (Male and female) in kid's black Bengal goats

\begin{tabular}{|c|c|c|c|c|}
\hline Parameter & Male & Female & Overall & SN \\
\hline $\begin{array}{c}\text { Birth Weight } \\
\text { (kg) }\end{array}$ & $\begin{array}{c}1.38 \pm 0.18^{b} \\
(2223)\end{array}$ & $\begin{array}{c}1.34 \pm 0.07^{\mathrm{a}} \\
(2027)\end{array}$ & $1.37 \pm 0.002^{\mathrm{a}}$ & $*$ \\
\hline $\begin{array}{c}3^{\text {rd }} \text { Months } \\
\text { (kg) }\end{array}$ & $\begin{array}{c}6.15 \pm 0.04^{b} \\
(1185)\end{array}$ & $\begin{array}{c}5.18 \pm 0.05^{\mathrm{a}} \\
(963)\end{array}$ & $\begin{array}{c}5.66 \pm 0.12^{a b} \\
(2148)\end{array}$ & $*$ \\
\hline $\begin{array}{c}6^{\text {th }} \text { Months } \\
\text { (kg) }\end{array}$ & $\begin{array}{c}8.23 \pm 0.20^{b} \\
(508)\end{array}$ & $\begin{array}{c}7.66 \pm 0.09^{a} \\
(420)\end{array}$ & $\begin{array}{c}7.93 \pm 0.11^{a b} \\
(928)\end{array}$ & $*$ \\
\hline $\begin{array}{c}9^{\text {th }} \text { Months } \\
\text { (kg) }\end{array}$ & $\begin{array}{c}12.74 \pm 0.14^{\mathrm{c}} \\
(443)\end{array}$ & $\begin{array}{c}10.55 \pm 0.18^{a} \\
(396)\end{array}$ & $\begin{array}{c}11.72 \pm 0.168^{b} \\
(839)\end{array}$ & $*$ \\
\hline $\begin{array}{l}12^{\text {th }} \text { Months } \\
\text { (kg) }\end{array}$ & $\begin{array}{c}14.92 \pm 0.44^{\mathrm{b}} \\
(277)\end{array}$ & $\begin{array}{c}13.08 \pm 0.15^{\mathrm{a}} \\
(164)\end{array}$ & $\begin{array}{c}14.00 \pm 0.31^{\mathrm{ab}} \\
(341)\end{array}$ & $*$ \\
\hline
\end{tabular}

Fig:- in parentheses indicate number of kids

$* \mathrm{P}<0.05, * * \mathrm{P}<0.01, \mathrm{NS}=$ Non-Significant

Table.3 Effect of Agro climatic zone and (cluster village) of growth Performance different black Bengal goats

\begin{tabular}{|c|c|c|c|c|c|c|}
\hline \multirow[t]{2}{*}{ Parameter } & \multicolumn{2}{|c|}{ Central and North Eastern Plateau } & \multirow{2}{*}{$\begin{array}{c}\text { Western Plateau } \\
\text { Tiko Mean } \pm \text { SE }\end{array}$} & \multirow{2}{*}{$\begin{array}{c}\text { Southern Plateau } \\
\text { Barabanki Mean } \pm \text { SE }\end{array}$} & \multirow{2}{*}{$\begin{array}{c}\text { Overall } \\
\text { Mean } \pm \text { SE }\end{array}$} & \multirow[t]{2}{*}{ SN } \\
\hline & $\begin{array}{l}\text { Chamguru } \\
\text { Mean } \pm \text { SE }\end{array}$ & Palajori Mean \pm SE & & & & \\
\hline Birth Weight & $1.34 \pm \underset{(1070)}{0.032^{\mathrm{a}}}$ & $\underset{(1030)}{1.36 \pm 0.02^{c}}$ & $1.44 \pm \underset{(986)}{0.062^{d}}$ & $1.35 \pm \underset{(1170)}{ \pm 0.002^{b}}$ & $1.37 \pm \underset{(4256)}{ \pm 0.002}$ & $*$ \\
\hline $3^{\text {rd }}$ Months & $\underset{(608)}{5.74 \pm 0.012^{d}}$ & $\underset{(499)}{5.66 \pm 0.12^{b}}$ & $\underset{(458)}{5.59 \pm 0.05^{\mathrm{a}}}$ & $\underset{(582)}{5.68 \pm 0.81^{\mathrm{c}}}$ & $\begin{array}{c}5.66 \pm 0.12 \\
(2148)\end{array}$ & $*$ \\
\hline $6^{\text {th }}$ Months & $7.77 \pm 0.15^{\mathrm{b}(242)}$ & $\underset{(212)}{8.56 \pm 0.11^{\mathrm{d}}}$ & $\underset{(210)}{7.78 \pm 0.15^{c}}$ & $7.55 \pm 0.11^{\mathrm{a}}$ & $\begin{array}{l}7.93 \pm 0.11 \\
(928)\end{array}$ & $*$ \\
\hline $9^{\text {th }}$ Months & $11.78 \pm 0.27^{c}$ & $\underset{(198)}{11.63 \pm 0.16^{a}}$ & $\underset{(185)}{11.65 \pm 0.54^{b}}$ & $11.85 \pm \frac{(218}{0.142^{\mathrm{d}}}$ & $\underset{(839)}{11.72 \pm 0.168}$ & $*$ \\
\hline $12^{\text {th }}$ Months & $14.85 \pm 1.39^{d}$ & $\underset{(87)}{13.43 \pm 0.31^{b}}$ & $\underset{(65)}{14.40 \pm 0.54^{\mathrm{c}}}$ & $\underset{(94)}{13.34 \pm 0.166^{\mathrm{a}}}$ & $\underset{(341)}{14.00 \pm 0.31}$ & $*$ \\
\hline
\end{tabular}

Fig:- in parentheses indicate number of kids

$* \mathrm{P}<0.05, * * \mathrm{P}<0.01, \mathrm{NS}=$ Non-Significant 
Table.4

\begin{tabular}{|c|c|}
\hline Parameter & Observation \\
\hline Number of Animals Available (No) & 4256 \\
\hline Number of Survivable Animals \\
( No) & 4076 \\
\hline Number of Dead Animals (No) & 180 \\
\hline Survivability \% & 95.77 \\
\hline Mortality \% & 4.22 \\
\hline
\end{tabular}

Table.5 Effect of age on Survivability percentage of black Bengal kids

\begin{tabular}{|c|c|c|c|c|c|}
\hline Parameter & $0-3$ Months & $3-6$ Months & $\begin{array}{c}6-9 \\
\text { Months }\end{array}$ & $\begin{array}{c}9-12 \\
\text { Months }\end{array}$ & Overall \\
\hline $\begin{array}{c}\text { Number of Animals } \\
\text { Available (No) }\end{array}$ & 2148 & 928 & 839 & 341 & 4256 \\
\hline $\begin{array}{c}\text { Number of Animals } \\
\text { Survivable(No) }\end{array}$ & 2032 & 889 & 818 & 337 & 4076 \\
\hline Survivability \% & 94.59 & 95.79 & 97.49 & 98.82 & 95.77 \\
\hline
\end{tabular}

Table.6 Effect of age on Mortality percentage of black Bengal kids

\begin{tabular}{|c|c|c|c|c|c|}
\hline Parameter & 0-3 Months & $3-6$ Months & $\begin{array}{c}6-9 \\
\text { Months }\end{array}$ & $\begin{array}{c}9-12 \\
\text { Months }\end{array}$ & Overall \\
\hline $\begin{array}{c}\text { Number of Animals } \\
\text { Available(No) }\end{array}$ & 2148 & 928 & 839 & 341 & 4256 \\
\hline $\begin{array}{c}\text { Number of Animals } \\
\text { Dead(No) }\end{array}$ & 116 & 39 & 21 & 4 & 180 \\
\hline Mortality \% & 5.40 & 4.20 & 2.50 & 1.17 & 4.22 \\
\hline
\end{tabular}

Fig.1 Effect of growth performance in different sex of (Male and Female) in kid's black Bengal goats Birth $\square$ Months $\square$ Months $\square$ Months $\square 12$ Months

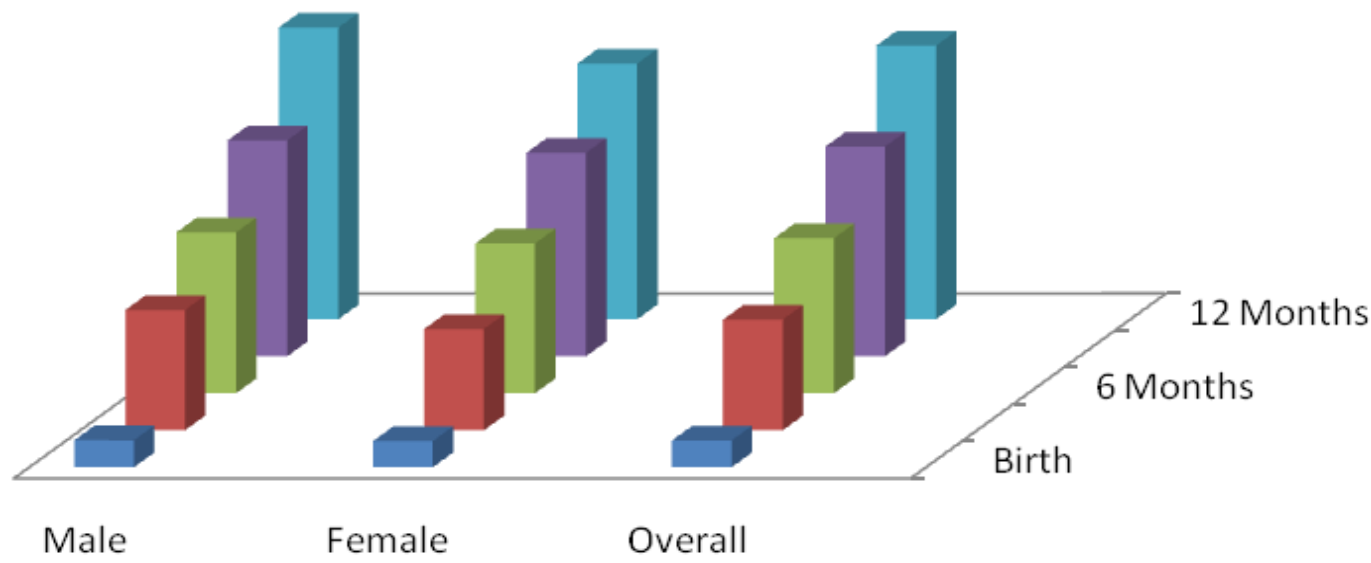


Fig.2 Effect of Agro climatic zone and (cluster village) of growth (productive) performance different black Bengal goats

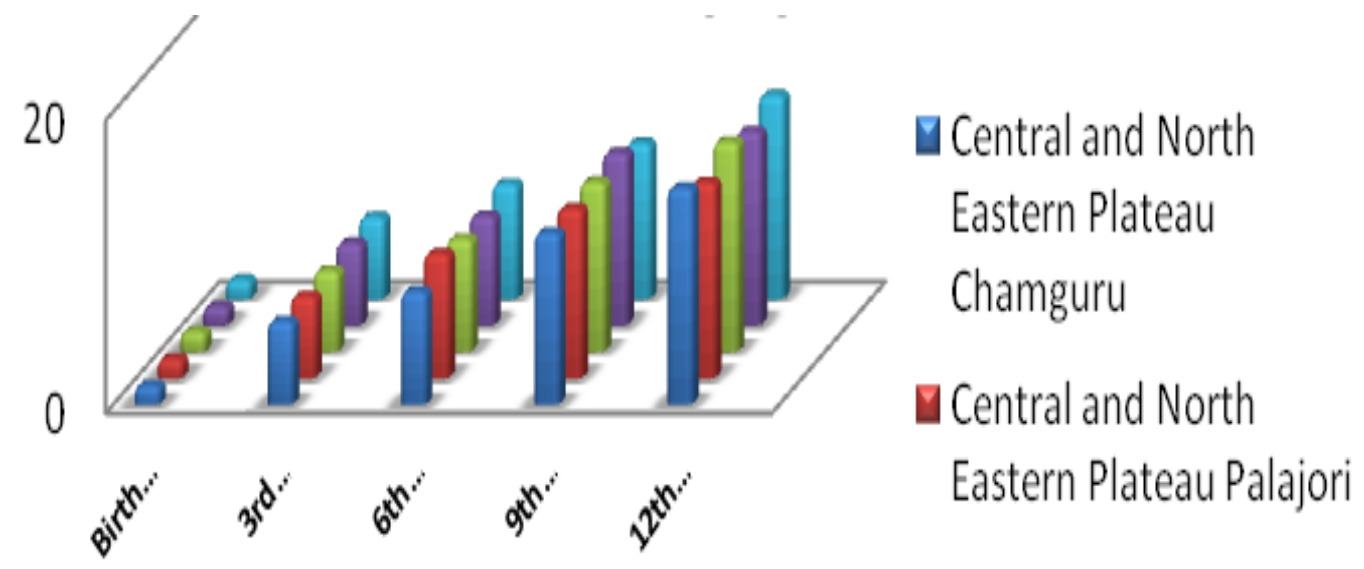

Fig.3 Average Survivability and Mortality of kids

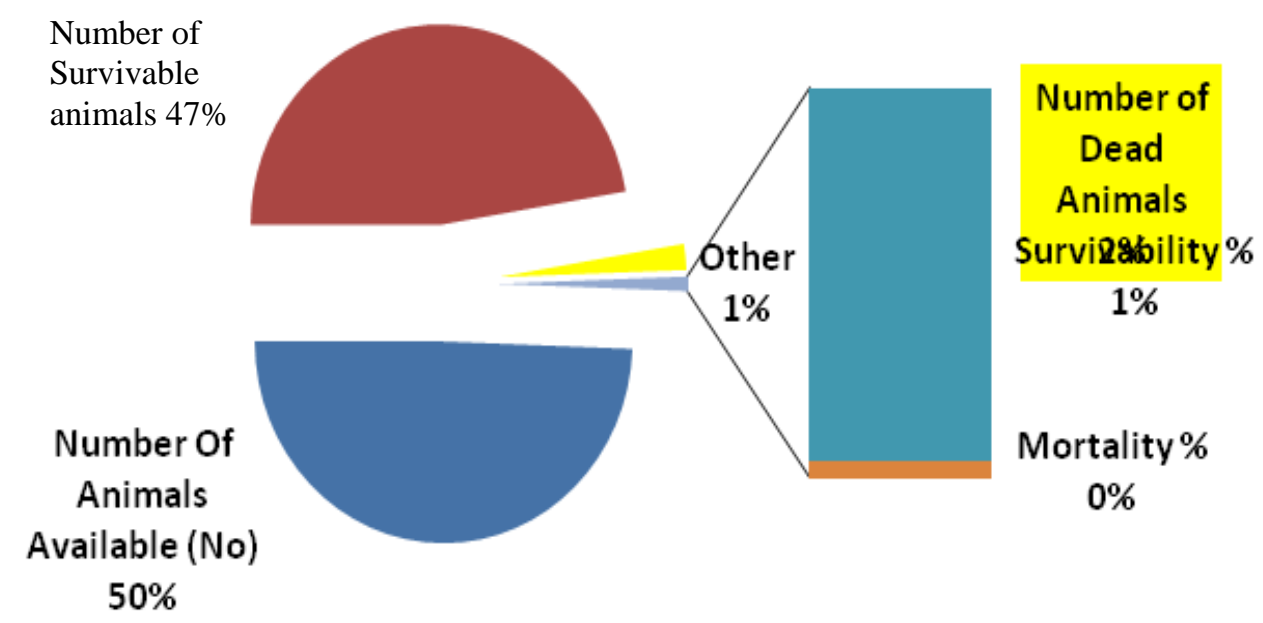

Fig.4 Effect of age on Survivability percentage of black Bengal kids



Number of animals

available

Number of animals

Survivable

Survivability \% 
Fig.5 Effect of age on Mortality percentage of black Bengal kids

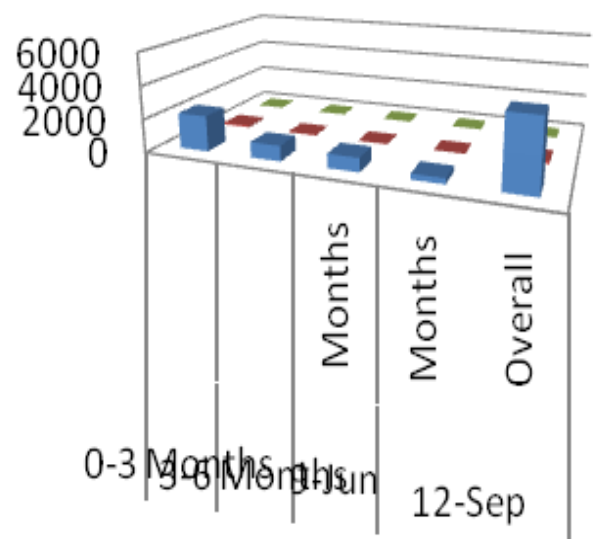

Number of animals available

Number of animals

Dead

Mortality \%

The body wt in this investigation was observed to be $11.48 \pm 0.81 \mathrm{~kg}$ is quite higher side of the earlier report $(8.80 \mathrm{~kg}$, Acharya, 1982 and $11.79 \mathrm{~kg}$, Singh, 1997) may be that the flock is of superior quality.

\section{Effect of Agro climatic zone of growth Performance different black Bengal goats}

The mean by months change in body weight of B.B. kids under different villages viz Chamguru, Palajori, Tiko and Brabanki are presented in tables 4.3 and figure 4.3.

Season had significant influence on body weight of kids from birth weight to 12 months of age. At birth weight the mean overall body weight of kids was observed $1.37 \pm 0.002 \mathrm{~kg}$ and ranges $1.34 \pm 0.003$ to $1.44 \pm 0.062 \mathrm{~kg}$ during different months under study. Significant different in body weight of birth $(p<0.05)$ were observed among different months. Highest birth weight were observed during village Tiko (1.44 \pm 0.062$)$ followed by Palajori (1.36 \pm 0.02$)$, barabanki (1.35 \pm 0.002$)$ and chamguru $1.34 \pm 0.003, \mathrm{~kg}$. At end of Tiko village $\left(12^{\text {th }}\right.$ months body weight of age) Significantly different highest body weight were observed during Chamguru 14.85 \pm 1.54 followed by Tiko $14.44 \pm 0.54$, palajori $13.43 \pm 0.31$ and barabanki $13.34 \pm 0.166 \mathrm{~kg}$.
Present finding are in conformity with finding.

\section{Survivability}

The production potential of any female is depend on how many live off-spring she produce and how much economic return a farmer get from those live off-springs. There by the information about the Survivability percentage of the black Bengal goat population is very much needed in order to ascertain the production potentiality of the breed. Survivability percentage was estimated during pre-weaning period at different age group viz 0-3 months, 4-6 months, 7-9 months and 10-12 months, were recorded.

\section{Effect of age on Survivability percentage of black Bengal kids}

Average Survivability percentages were observed to be overall 97.77 and survivability percentage $94.59,95.79,97.5$, and $98.8 \%$ during the period $0-3,4-6,7-9$ and 10-12 months of age. Highest survivability \% were observed during age 10-12 months (98.8\%) Followed by 7 to 9 months (97.9\%), 4 to 6 months $(95.79 \%)$ and 0 to 3 months $(94.59 \%)$ respectively (Tables 4.2 and figure 4.2) the result clearly indicated that Survivability percentages to the age of 0 to 12 months. The 
result further indicated they we have to take care of kids on 4-9 months of age as compared to higher age to reduce the mortality percentage.

The highest mortality was observed during 030 days age (13.19\%), as also reported by Ali et al., (1975), Majumder et al., (1980), Srivastava et al., (1986), Singh et al., (1990) and Hossain et al., (2004). The kid mortality as found in this study was towards the lower side as compared to other workers reported earlier.

However Mittal (1976) commented that neither breeds, sex, type of birth not even season of kidding influenced the mortality rate of kids. Pneumonia was responsible for the highest losses

\section{Effect of age on Mortality percentage of black Bengal kids}

Average mortality percentage overall 4.22 and during period was observed to be 5.41, 4.2, 2.5, and $1.2 \%$ during the period $0-3,4-6,7-9$ and 10-12 months of age. Highest mortality \% were observed during age 0 to 3 months (5.41\%), Followed by 4 to 6 months $(4.2 \%), 7$ to 9 months $(2.1 \%)$ and $10-12$ months $(1.2 \%)$ ) respectively (Tables 4.3. and figure 4.3.) the result clearly indicated that Survivability percentages to the age of 0 to 12 months.

The result further indicated they we have to take care of kids on 0-3 months of age as compared to higher age to reduce the mortality percentage. The highest mortality was observed during 0-30 days age (13.19\%), as also reported by Ali et al., (1975), Majumder et al., (1980), Srivastava et al., (1986), Singh et al., (1990) and Hossain et al., (2004). The kid mortality as found in this study was towards the lower side as compared to other workers reported earlier. However Mittal (1976) commented that neither breeds, sex, type of birth not even season of kidding influenced the mortality rate of kids. Pneumonia was responsible for the highest losses.

\section{References}

Ali, S. Z. (1980). Relation of birth weight of kids to their postnatel growth in Black Bengal goats. Indian veterinary journal., 57(12): 1006- 1008. Das, A. K., Manna, M. K., Sahoo, A. K., Deb, R. and Paul,

Ali, S. Z., Hoque, M. M. and Hasnath, M. A. (1973). A study on the growth and reproductive performance of Black Bengal goats under farm Conditions. Indian veterinary journal., 50(5): 438-440.

Bansod, R. S., Jagtap, O. Z. and Belhe, N. D. (1992). Influence of Himachal and Texas buck on reproductive traits in Angora. Indian J. Anim Prod. Mgmt., 10(4): 163 164.

Barding, R. P., P. M. Mohite, G. R. Patil and R. L. Dhoble. (2000). Effect of season on kidding birth weight and preweaning mortality in Osmanabadi goats. Proceedings, the 7th International Conference on Goat. 15-21 May, FranceParis. pp. 742-743.

Dey, A., Barari, S. K. and Yadav, B. S. P. (2007). Goat production scenario in Bihar, India. Livestock Research for Rural Development., 19(9).

Dhara, K. C., Ray, N., Roy, S., Samanta, A. K. and Senapati, P. K. (2008). Improvement of Reproductive Performance of Black Bengal Goat through Selection under Field Condition. J. Anim. Vet. Adv., 7 (5): 599-603.

R. K. (2008). Studies on reproductive traits of Bengal goats in a part of West Bengal. Indian journal of Small ruminants., 14(2): 259-261.

Das, S. K. and Roy, S. K. (1999). A study on the birth weight of Bengal kids. Indian Vet. Med. Jour., 23: 123- 124.

Dhara, K.C., Ray, N., Roy, S., Samanta, A.K. and Senapati, P.K. (2008). Improvement 
of Reproductive Performance of Black Bengal Goat through Selection under Field Condition. J. Anim. Vet. Adv., 7 (5): 599-603.

Devendra, C. (2001). Small ruminants: Imperatives for productivity enhancement, improved livelihoods and rural growth- A review. Asian-Australian Journal of Animal Sciences., 14(10): 1483-1496.

Faruque, S., Husain, S.S., Rahman, M. M., Ray, B. K., Islam, M. N. and Islam, M. S. (2002). A study on the reproductive performance of does in different genetic groups under village condition. Journal of Bio. Sci., 2(5): 325-328. Faruque, S., Husain, S. S., Rahman, M. M., Ray, B. K., Islam, M. N. and Islam, M. S. (2002). A study on the reproductive performance of does in different genetic groups under village condition. Journal of Bio. Sci., 2(5): 325-328.

Genetic Resource. (2008). DARE / ICAR Annual repot 2007-2008. pp.17.

Ghosh, S. K. and Das, A. (1999). Effect of sex and type of kidding on gestation length and birth weight in Black Bengal goats. Jndian J. Anim. Reprod., 20(1): 43-44.

Greyling, J. P. C. (1988). Reproductive physiology in the Boer goat doe. In: reproduction traits in the Boer goat doe. Small Ruminant Research., 36: 171-177.

Lawar, V. S., Bhoite, V. Y. and Rasane, D. S. (2001). Effect of season of previous kidding on kidding interval in Angora and its crosses. Indian Vet. J., 78: 337 - 338.

Mishra, S. K. and Sinha, R. (2001). Studies on the incidence of multiple birth and reproduction of Black Bengal goat under village conditions. J. Interacad., 5(2): 212215.

Mukundan. G., Bhat, P. N. and Khan, B. U. (1981). Genetic analysis of birth weight in Malabari breed of goat and its half-breeds. Indian J. Anim. Sci., 51(6): 603 - 634.

Singh, D. K. (1999). Factors affecting body weight and measurements of Black Bengal and its half bred kids at birth. Indian Veterinary Medical journal., 23: 27-30.

Singh, R. N. and Acharya, R. M. (1983). Optima for age at first kidding, first lactation length and first kidding interval in relation to lifetime production. Indian J. Dairy Sci., 36(3): 298 - 301. Singh, D.

Singh, K., C. S. P. and Mishra, H. R. (1990). Birth weight of pure and crossbred kids under extensive system of management in villages. Indian J. Anim. Sci., 60(3): 375377.

Singh, D. K., Singh, C. S. P. and Singh, L. B. (1987). Reproductive traits of Black Bengal. Indian J. of Anim. Sci., 57(6): 605 $-608$.

Srivastava, A. K., Patil, V. K. and More, B. K. (1986). Causes of mortality in local, Angora and crossbred kids under the subtropical agro-climatic conditions of Maharashtra. Livestock Adviser., 11: 4044.

Zeshmarani, S., Dhara, K. C., Samanta, A. K., Samanta, R. and Majumder, S. C. (2007). Reproductive performance of Goats in Eastern and North-eastern India. Livestock Research for Rural Development., 19(8).

\section{How to cite this article:}

Mukesh Kumar, Sushil Prasad, Ravindra Kumar, Soumen Naskar, Pankaj kumar, Pawan kumar verma and Nandani kumari. 2021. Study on different Agro Climatic Zone Wise of Black Bengal Goats Production Performance Suitable for Farming System in Jharkhand. Int.J.Curr.Microbiol.App.Sci. 10(06): 236-244. doi: https://doi.org/10.20546/ijcmas.2021.1006.025 